\title{
Pendekatan Fenomenologi: Pengantar Praktik Penelitian dalam Ilmu Sosial dan Komunikasi
}

\author{
O. Hasbiansyah \\ ABSTRACT \\ Phenomenology, initially, is a philosophy made popular by Edmund Husserl. Phenomenology, \\ in essential, taught people to interact and learn more from phenomenon so that the meaning \\ of reality, and the natural essence of reality, could be grasped by the observer. \\ Phenomenology today develops as one of fundamental research method whose assumptions \\ respect human uniqueness and subjective experiences. Phenomenon as experienced consciously \\ by human was analyzed by two descriptions: textual description and scriptural description.
}

Kata kunci: fenomenologi, fenomena, metode riset.

\section{Pendahuluan}

Fenomenologi, pada awalnya, merupakan kajian filsafat dan sosiologi. Edmund Husserl sendiri, penggagas utamanya, menginginkan fenomenologi akan melahirkan ilmu yang lebih bisa bermanfaat bagi kehidupan manusia, setelah sekian lama ilmu pengetahuan mengalami krisis dan disfungsional. Fenomenologi, kemudian, berkembang sebagai semacam metode riset yang diterapkan dalam berbagai ilmu sosial, termasuk di dalamnya komunikasi, sebagai salah satu varian dalam penelitian kualitatif dalam payung paradigma interpretif.

Dalam pengertian sederhana, sesungguhnya kita pada waktu-waktu tertentu mempraktikkan fenomenologi dalam keseharian hidup kita. Kita mengamati fenomena, kita membuka diri, kita membiarkan fenomena itu tampak pada kita, lalu kita memahaminya. Kita memahaminya dalam perspektif fenomena itu sendiri, bagaimana ia "bercerita" kepada kita.

Kata Brouwer (1984:3), seorang fenomenolog senang melihat gejala (fenomena). Melihat gejala merupakan dasar dan syarat mutlak untuk semua aktivitas ilmiah. Ia bukan ilmu, tetapi merupakan cara pandang, metode pemikiran, a way of looking at things. Untuk meyakinkan orang atas suatu fenomena, seorang fenomenolog akan mengajak orang untuk menyaksikan langsung fenomena yang bersangkutan, atau menujukkannya melalui bahasa. Untuk memahami suatu gejala, maka tak ada jalan lain, kita harus sabar menyaksikannya, mendengarkannya, menyelami bahasa yang diungkapkannya.

Bagi Brouwer, fenomenologi tidak bisa hilang dan menjadi syarat mutlak bagi seseorang yang mau memikirkan dasar dari usaha ilmiah atau dasar dari hidupnya sendiri. Lebih jauh, fenomenologi mengajarkan kita untuk membiasakan diri, tidak lagi melihat benda-benda, melainkan melihat fenomena.

Fenomenologi, dengan demikian, secara 
sederhana dapat dipandang sebagai sikap hidup dan sebagai metode ilmiah. Sebagai sikap hidup, fenomenologi mengajarkan kita untuk selalu membuka diri terhadap berbagai informasi dari mana pun berasal, tanpa cepat-cepat menilai, menghukumi, atau mengevaluasi berdasarkan prakonsepsi kita sendiri. Kita berdialog dengan fenomena yang kita hadapi. Kita membiarkan fenomena itu "membuka mulutnya", bercerita tentang dirinya: kita bertanya, mendengarkan, dan menangkap pola serta maknanya. Sebagai metode ilmiah, fenomenologi menunjukkan jalan perumusan ilmu pengetahuan melalui tahap-tahap tertentu, di mana suatu fenomena yang dialami manusia menjadi subjek kajiannya. Tulisan ini membatasi diri hanya akan menguraikan fenomonlogi sebagai metode ilmiah dalam penelitian ilmu-ilmu sosial.

\section{Sekilas Latar Belakang Historis Fenomenologi}

Pada awalnya, istilah fenomenologi diperkenalkan oleh J.H. Lambert, tahun 1764, untuk menunjuk pada Teori Kebenaran (Bagus, 2002:234). Setelah itu, istilah ini diperluas pengertiannya. Sedangkan menurut Kockelmans (1967, dalam Moustakas 1994:26), fenomenologi digunakan dalam filsafat pada tahun 1765, yang kadangkadang ditemukan dalam karya-karya Immanuel Kant, yang kemdian didefinisikan secara baik dan dikonstruksikan sebagai makna secara teknis oleh Hegel. Menurut Hegel, fenomenologi berkaitan dengan pengetahuan yang muncul dalam kesadaran, sains yang mendeskripsikan apa yang dipahami seseorang dalam kesadaran dan pengalamannya.

Fenomenologi dicetuskan secara intens sebagai kajian filsafat pertama kali oleh Edmund Husserl (1859-1938), sehingga Husserl sering dipandang sebagai Bapak Fenomenologi. Filsafatnya sangat populer sekitar tahun 1950-an. Tujuan utama filsafat ini adalah memberi landasan bagi filsafat agar dapat berfungsi sebagai ilmu yang murni dan otonom (Kuper dan Kuper, ed., 1996:749). Pada awal perekembangannya, fenomenologi merupakan seperangkat pendekatan dalam studi filosofis dan sosiologis, serta studi tentang seni (Edgar dan Sedgwick, 1999:271).

Kemunculan fenomenologi oleh Husserl dilatarbelakangi oleh kenyataan terjadinya krisis ilmu pengetahuan. Dalam krisis ini, ilmu pengetahuan tidak bisa memberikan nasihat apaapa bagi manusia. Ilmu pengetahuan senjang dari praktik hidup sehari-hari. Hal ini, menurut Husserl, konsep teori sejati telah banyak dilupakan oleh banyak disiplin yang maju dalam kebudayaan ilmiah dewasa ini. Sehubungan dengan itu, Husserl mengajukan kritik terhadap ilmu pengetahuan sebagai berikut:

(1) Ilmu pengetahuan telah jatuh pada objektivisme, yaitu cara memandang dunia sebagai susunan fakta objektif dengan kaitankaitan niscaya. Bagi Husserl, pengetahuan seperti itu berasal dari pengetahuan prailmiah sehari-hari, yang disebut lebenswelt.

(2) Kesadaran manusia atau subjek ditelan oleh tafsiran-tafsiran objektivistis itu, karena ilmu pengetahuan sama sekali tidak membersihkan diri dari kepentingan-kepentingan dunia kehidupan sehari-hari itu.

(3) Teori yang dihasilkan dari usaha membersihkan pengetahuan dari kepentingan-kepentingan itu adalah teori sejati yang dipahami tradisi pemikiran Barat.

Dengan demikian, menurut Husserl, krisis ilmu pengetahuan itu disebabkan oleh kesalahpahaman disiplin-disiplin ilmiah itu terhadap konsep teori sejati itu. Melalui fenomenologi, Husserl berusaha menemukan hubungan antara teori dengan duniakehidupan yang dihayati, yang tujuan akhirnya untuk menghasilkan teori murni yang dapat diterapkan pada praktik (Hardiman, 1993: 5). Dengan kata lain, fenomenologi Husserl ini berangkat dari filsafat ilmu. Dalam hal ini, ia mengsusulkan bahwa fenomena-fenomena itu, untuk dipahami, harus didekati dengan cara-cara yang khas.

Edmund Husserl menyatakan bahwa pengetahuan ilmiah sebenarnya telah terpisahkan dari pengalaman sehari-hari dari kegiatan-kegiatan di mana pengalaman dan pengetahuan itu berakar 
Terakreditasi Dirjen Dikti SK No. 56/DIKTI/Kep/2005

(Maliki, 2003:233). Maka itu, ia menawarkan fenomenologi. Konsep fenomenologi Husserl dipengaruhi oleh konsep verstehen dari Max Weber. Verstehen adalah pemahaman. Realitas adalah untuk dipahami, bukan untuk dijelaskan.

Menurut Bertens (1981:99), apa yang disebut "metode fenomenologi" saat ini kerap kali hampir tidak berkaitan lagi dengan fenomenologi menurut konsepsi Husserl. Ia memahami fenomenologi sebagai suatu analisis deskriptif serta introspektif mengenai kedalaman dari semua bentuk kesadaran dan pengalaman langsung (Bagus, 2002:236). Fokus filsafat, baginya, adalah lebenswelt (dunia kehidupan) dan erlebnisse (kehidupan subjektif dan batiniah). Bagi Husserl, fenomenologi merupakan kajian filosofis yang melukiskan segala bidang pengalaman manusia. Manusia mengalami pengalaman hidupnya dalam sebuah kesadaran. Baginya, fenomenolgi merupakan sebuah kajian yang tak pernah berakhir, sehingga ia menjuluki dirinya sebagai pemula yang abadi. Oleh karena itu, fenomenologi, kini, telah banyak dikupas, dan diberi penjelasan yang begitu luas dan beragam. Husserl sendiri bercita-cita, fenomenologi menjadi ilmu rigorous, yakni ilmu yang "ketat" yang penjelasannya punya batasan, tidak meragukan. Setiap konsep terdefinisikan dengan jelas.

Husserl mengembangkan sistem filosofis yang berakar dari keterbukaan subjektif, sebuah pendekatan radikal terhadap sains yang terus dikritisi. Fenomenologi, bagi Husserl, tak berguna bagi mereka yang berpikiran tertutup (lihat Moustakas, 1994:25). Seorang fenomenolog adalah orang yang terbuka pada realitas dengan segala kemungkinan rangkaian makna di baliknya, tanpa tendensi mengevaluasi atau menghukumi.

Fenomenologi Husserl, menurut Bertens, pada akhirnya berdimensi sejarah. Suatu fenomena tidaklah sebagai sesuatu yang statis, tetapi dinamis. Fenomena itu memiliki sejarah. Sejarah berkaitan dengan riwayat individual manusia, juga manusia secara keseluruhan. Kesadaran kita mengalami perkembangan; sejarah kita selalu hadir dalam cara kita menghadapi realitas. Setiap fenomena mengandung muatan sejarah. Suatu fenomena tidak beridiri sendiri, tetapi memiliki kaitan dengan peristiwa-peristiwa sebelumnya.

Setelah Husserl, fenomenologi berkembang, antara lain, dalam pemikiran Morleau-Ponty, Alfred Schutz, Peter L. Berger, dan Thomas Luckmann. Pandangan Husserl berbeda dengan padangan para fenomenolog berikutnya. Bagi Husserl, pengalaman merupakan sesuatu yang bersifat objektif, terpisahkan dari individu.

Maurice Morleau-Ponty banyak dipengaruhi pemikiran Husserl. Tetapi, ia menolak idealisme Husserl. Bagi Morleau-Ponty, manusia adalah kesatuan dari dimensi fisik dan nonfisik yang menciptakan makna dalam dunia. Seseorang, sebagai subjek pengamat, memiliki relasi dengan sesuatu di dunia ini. Ia dipengaruhi oleh dunia dan pada gilirannya ia pun memaknai dunia itu.

Dunia yang kita alami merupakan hasil ciptaan kesadaran kita. Fenomenologi memang mengakui adanya realitas eksternal sebagai hal yang benarbenar ada, tetapi hal itu hanya bisa dipahami melalui kesadaran yang kita miliki.

Menurut Alfred Schutz, proses pemaknaan diawali dengan proses penginderaan, suatu proses pengalaman yang terus berikesinambungan. Arus pengalaman inderawi ini, pada awalnya, tidak memiliki makna. Makna muncul ketika dihubungkan dengan pengalaman-pengalaman sebelumnya serta melalui proses interaksi dengan orang lain. Karena itu, ada makna individual, dan ada pula makna kolektif tentang sebuah fenomena. Kesadaran kita memproses data inderawi. Bagi Schutz, tindakan manusia selalu punya makna menurut Weber makna itu identik dengan motif tindakan. Namun, makna itu tidak ada yang bersifat aktual dalam kehidupan.

Lebih jauh, Peter L. Berger dan Thomas Luckmann menyatakan bahwa manusia mengonstruksi realitas sosial melalui proses subjektif, tetapi dapat berubah menjadi objektif. Proses konstruksi terjadi melalui pembiasaan di antara para aktor. Hubungan antarindividu dengan institusi terjadi secara dialektik. "Masyarakat adalah produk manusia, masyarakat adalah realitas objektif, dan manusia produk masyarakat." Proses itu terjadi melalui hubungan memori dari pengalaman dan peran individu. Manusia adalah 
produk dari masyarakat yang diciptakannya sendiri.

Selain itu, fenomenologi berfokus pada pengalaman personal, termasuk bagaimana para individu mengalami satu sama lain (Littlejohn, 2002:13). Oleh karena itu, komunikasi dipandang sebagai hubungan antarpribadi secara bersama melalui dialog.

\section{Beberapa Pengertian dan Kosep Dasar Fenomenologi}

Fenomenologi berasal dari bahasa Yunani, phaenesthai, berarti menunjukkan dirinya sendiri, menampilkan. Fenomenologi juga berasal dari bahasa Yunani, pahainomenon, yang secara harfiah berarti "gejala" atau apa yang telah menampakkan diri" sehingga nyata bagi si pengamat. Metode fenomenologi yang dirintis Edmund Husserl bersemboyan: Zuruck zu den sachen selbst (kembali kepada hal-hal itu sendiri) (Dister Ofm, dalam Suprayogo dan Tobroni, 2003:102). Untuk memahami apa yang sesungguhnya terjadi perceraian di kalangan artis, misalnya, menurut semboyan ini, maka peneliti harus menanyakannya kepada artis yang mengalaminya, bukan kepada yang lain.

Fenomenologi, sesuai dengan namanya, adalah ilmu (logos) mengenai sesuatu yang tampak (phenomenon). Dengan demikan, setiap penelitian atau setiap karya yang membahas cara penampakan dari apa saja merupakan fenomenologi (Bertens, 1987:3). Dalam hal ini, fenomenologi merupakan sebuah pendekatan filsafat yang berpusat pada analisis terhadap gejala yang membanjiri kesadaran manusia (Bagus, 2002:234). Fenomenologai adalah studi tentang pengetahuan yang berasal dari kesaradan, atau cara memahami suatu objek atau peristiwsa dengan mengalaminya secara sadar (Littlejohn, 2003:184). Namun, bagi Brouwer (1984:3), fenomenologi itu bukan ilmu, tetapi suatu metode pemikiran (a way of looking at things). Dalam fenomenologi tidak ada teori, tidak ada hipotesis, tidak ada sistem.

Fenomenologi bukan realisme, juga bukan idealisme. Di satu sisi, fenomenologi percaya bahwa dunia itu ada, real. Dunia, dengan segala isinya, itu nyata ada, tanpa pengaruh kehadiran pikiran kita. Ada atau tidak ada kita, kita berpikir atau tidak, dunia itu hadir sebagaimana adanya. Tetapi fenomenologi tidak sama dengan realisme yang hanya percaya atas realitas sebagai hal objektif terpisah dari kesadaran. Di sisi lain, fenomenologi juga mengajarkan bahwa realitas itu muncul dalam proses aktif dalam kesadaran, tetapi tidak sama seperti idealisme yang menafikan realitas objektif (lihat Delfgaauw, 2001:105). Jadi, fenomenologi menempati kedudukan sebelum terdapatnya pembedaan antara realisme dengan idealisme. Namun, Husserl secara berangsur-angsur berpaling ke arah idealisme. Sementara, muridmuridnya lebih menuju ke bandul realisme.

Fenomenologi juga berupaya mengungkapkan tentang makna dari pengalaman seseorang. Makna tentang sesuatu yang dialami seseorang akan sangat tergantung bagaimana orang berhubungan dengan sesuatu itu (lihat Edgar dan Sedgwick, 1999:273). Sejalan dengan itu, menurut Littlejohn dan Foss (2005:38), fenomenologi berkaitan dengan penampakan suatu objek, peristiwa, atau suatu kondisi dalam persepsi kita. Pengetahuan berasal dari pengalaman yang disadari, dalam persepsi kita. Dalam hal ini, fenomenologi berarti membiarkan sesuatu datang mewujudkan dirinya sebagaimana adanya. Dengan demikian, di satu sisi, makna itu muncul dengan cara membiarkan realitas/fenomena/pengalaman itu membuka dirinya. Di sisi lain, makna itu muncul sebagai hasil interaksi antara subjek dengan fenomena yang dialaminya.

Berikut adalah bebeapa pengertian fenomenologi lainnya:

- Fenomenologi adalah studi tentang esensiesensi, misalnya esensi persepsi, esensi kesadaran, dsb.

- Fenomenlogi merupakan filsafat yang menempatkan kembali esensi-esensi dalam eksistensi; bahwa manusia dan dunia tak dapat dimengerti kecuali dengan bertitik tolak pada aktivitasnya.

- Fenomenologi adalah suatu filsafat transendental yang menangguhkan sikap natu- 
ral dengan maksud memahaminya secara lebih baik.

- Fenomenologi merupakan filsafat yang menganggap dunia selalu "sudah ada", mendahului refleksi, sebagai suatu kehadiran yang tak terasingkan, yang berusaha memulihkan kembali kontak langsung dan wajar dengan dunia sehingga dunia dapat diberi status filosofis.

- Fenomenologi adalah ikhtiar untuk secara langsung melukiskan pengalaman kita sebagaimana adanya, tanpa memperhatikan asalusul psikologisnya dan keterangan kausal yang dapat disajikan oleh ilmuwan, sejarawan, dan sosiolog (lihat Merleau-Ponty dalam Bertens, ed., 1987: 27).

Lebih jauh, berkaitan dengan ilmu pengetahuan, Merleau-Ponty (dalam Bertens, ed. (1987: 30) menulis:

Saya tidak dapat mengerti diri saya sebagai sebagian dari dunia saya atau sebagai semata-mata objek penyelidikan biologi, psikologi, dan sosiologi. Saya juga tidak dapat membiarkan diri saya terkurung dalam dunia ilmu pengetahuan. Apa saja yang saya ketahui tentang dunia, bahkan melalui ilmu pengetahuan, saya mengetahuinya dari sudut pandangan saya yang khas atau berdasarkan pengalaman saya tentang dunia. Dan tanpa pengalaman-pengalaman itu, simbol-simbol pengetahuan takkan mempunyai arti apa pun. Seluruh ilmu pengetahuan dibangun atas di atas dunia yang dialami. Dan kalau kita ingin merefleksikan ilmu pengetahuan secara mendalam dan menentukan dengan tepat makna serta jangkauannya, maka terlebih dahulu perlu kita menghidupkan kembali pengalaman kita tentang dunia. Ilmu pengetahuan hanyalah pengungkapan kedua tentang dunia. Ilmu pengetahuan belum pernah dan tidak akan pernah mempunyai arti yang sama seperti dunia yang kita alami secara langsung, karena ilmu pengetahuan itu hanya sekadar penentuan dan keterangan lebih lanjut dari pengalaman kita.

Intisari fenomenologi dikemukakan Stanley Deetz (dalam Littlejohn dan Foss, 2005:38). Pertama, pengetahuan adalah hal yang disadari.
Pengetahuan tidak disimpulkan dari pengalaman tetapi ditemukan langsung dalam pengalaman kesadaran. Kedua, makna dari sesuatu terdiri dari potensi-potensi dalam kehidupan seseorang. Bagaimana hubungan seseorang dengan suatu objek akan menentukan bagaimana makna objek itu bagi yang bersangkutan. Ketiga, bahasa merupakan sarana bagi munculnya makna. Kita mengalami dunia dan mengekspresikannya melalui bahasa.

Untuk memahami fenomenologi, terdapat beberapa konsep dasar yang perlu dipahami, antara lain konsep fenomena, epoche, konstitusi, kesadaran, dan reduksi.

\subsection{Fenomena ${ }^{2}$}

Secara etimologis, istilah fenomena berasal dari kata Yunani: phaenesthai, artinya memunculkan, meninggikan, menunjukkan dirinya sendiri. Menurut Heidegger (Moustakas, 1994:26), istilah fenomena, yang juga dibentuk dari istilah phaino, berarti membawa pada cahaya, menempatkan pada terang-benderang, menunjukkan dirinya sendiri di dalam dirinya, totalitas dari apa yang tampak di balik kita dalam cahaya.

Objek yang muncul dalam kesadaran berbaur dengan objek yang ada secara alamiah, sehingga makna diciptakan dan pengetahuan dikembangkan. Suatu hubungan berada antara yang ada dalam kesadaran yang disadari dan apa yang berada dalam dunia. Apa yang muncul dalam kesadaran adalah realitas absolut sedangkan apa yang muncul di dunia adalah suatu produk belajar (Moustakas, 1994:27).

Fenomena adalah suatu tampilan objek, peristiwa, dalam persepsi. Sesuatu yang tampil dalam kesadaran. Bisa berupa hasil rekaan atau kenyataan. Menurut Moustakas (1994:26), fenomena adalah apa saja yang muncul dalam kesadaran. Fenomena, dalam konsepsi Huesserl, adalah realitas yang tampak, tanpa selubung atau tirai antara manusia dengan realitas itu. Fenomena adalah realitas yang menampakkan dirinya sendiri kepada manusia. Sementara itu, dalam mengahadapi fenomena itu manusia melibatkan 
kesadarannya, dan kesadaran selalu berarti kesadaran akan sesuatu (realitas) (Bertens, 1981:201).

Perlu dipahami, bahwa fenomena, menurut Brouwer (1984), bukanlah suatu benda, bukan suatu objek di luar diri kita, dan lepas dari kita sendiri. Ia adalah suatu aktivitas. Bila saya melihat sebuah rumah, maka terdapat aktivitas akomodasi, konvergensi, dan cerapan dari mata saya, sehingga rumah itu tampak terlihat, sehingga ia muncul sebagai fenomena. Secara sederhana, maka terjadi dialektis antara subjek dan objek. Tak mungkin ada yang dilihat jika tidak ada yang melihat.

Lebih lanjut, setiap fenomena merepresentasikan titik permulaan yang pas bagi suatau investigasi (Moustakas, 1994:26). Fenomena menjadi sesuatu yang menjadi objek yang dikaji dalam studi fenomenologi.

\subsection{Kesadaran}

Kesadaran adalah pemberian makna yang aktif. Kita selalu mempunyai pengalaman tentang diri kita sendiri, tentang kesadaran yang identik dengan diri kita sendiri. Dunia sebagai kebertautan fenomena-fenomena diantisipasi dalam kesadaran akan kesatuan kita dan bahwa dunia itu merupakan sarana bagi kita untuk merealisasikan diri kita sebagai kesadaran.

Kesadaran adalah kemampuan untuk memperlakukan subjek untuk menjadi objek bagi dirinya sendiri, atau menjadi objektif tentang dirinya sendiri (Bagus, 2002:232). Saya menjumpai hakikat kesadaran, bila saya menemukan kembali kehadiran saya pada diri saya sendiri, kenyataan kesadaran yang akhirnya mau ditunjukkan oleh kata dan pengertian "kesadaran" (Bertens, 1987:45).

Dunia adalah apa yang kita persepsi akan sesuatu. Dalam hal ini, Merleau-Ponty menekankan bahwa kesadaran tidak berfungsi di atas, melainkan di dalam dunia yang dimengertinya, dalam arti prareflektif dan praobyektif(Bertens, 1987:48).

Kesadaran, tak lain, adalah keterbukaan dan kelangsungan hubungan dengan yang lain, di mana dirinya dengan yang lainnya tidak memiliki pemisahan yang tegas.

\subsection{Intensionalitas}

Menurut Husserl, kesadaran bersifat intensionalitas, dan intensionalitas merupakan struktur hakiki kesadaran manusia. Oleh karena itu, fenomena harus dipahami sebagai hal yang menampakkan dirinya (Bertens, 1981:201). Dalam fenomenologi, intensionalitas mengacu pada keyakinan bahwa semua tindakan (aktus) kesadaran memiliki kualitas; atau seluruh kesadaran akan objek-objek. Tindakan kesadaran disebut tindakan intensional dan objeknya disebut objek intensional (Bagus, 2002:261-362). Menurut konsep ini, manusia menampakkan dirinya sebagai yang transenden, sintesis dari subjek dan objek. Manusia mengada dalam alam, menjadi satu dalam alam. Oleh karena itu, kata Brouwer (1984:6), tidak ada bedanya antara saya-mengalami-alam dengan alam-yang saya-alami. Intensi sendiri berarti orientasi pikiran pada suatu objek. Intensionalitas berkaitan dengan kesadaran, pengalaman internal mengenai kesadaran akan sesuatu.

\subsection{Konstitusi}

Konstiusi adalah proses tampaknya fenomena ke dalam kesadaran (Bertens, 1981:202). Ia merupakan aktivitas kesadaran, sehingga realitas itu tampak. Dunia nyata itu dikonstitusi oleh kesadaran. Kenyataan real bukan berarti ada karena diciptakan oleh kesadaran, tetapi kehadiran aktivitas kesadaran ini diperlukan agar penampakan fenomena itu dapat berlangsung. Bertens (1981:202) menegaskan:

Tidak ada kebenaran-pada-dirinya, lepas dari kesadaran. Dan karena yang disebut "realitas" itu tidak lain daripada dunia sejauh dianggap benar, maka realitas itu harus dikonstitusi oleh kesadaran. Konstitusi itu berlangsung dalam proses penampakan yang dialami oleh dunia ketika menjadi fenomen bagi kesadaran intensional.

Dengan kata lain, konstitusi itu semacam proses konstruksi dalam kesadaran manusia. Ketika kita melihat satu bentuk benda, yang tampak pada indra kita selalu hanya sebagian. Ia tampak dari mana kita melihat. Tetapi, kesadaran kita 
melakukan konstitusi, sehingga kita menyadarinya tentang (kemungkinan) bentuk benda itu bila dilihat dari sisi lain. Konstiusi adalah hal yang dilihat dari sudut pandang subjek, memaknakan dunia dan alam semesta yang dialami.

\subsection{Epoche}

Epoche merupakan konsep yang dikembangkan oleh Husserl, yang terkait dengan upaya mengurangi atau menunda penilaian (bracketing) untuk memunculkan pengetahuan di atas setiap keraguan yang mungkin. Sejalan dengan Descartes dan Kant, Husserl berpendapat bahwa pengetahuan berasal dari intuisi, dan esensi mendahului pengetahuan empiris.

Epoche berasal dari bahasa Yunani, yang berarti menahan diri untuk menilai. Dalam sikap alamiah sehari-hari, kita memperoleh pengetahuan melalui penilaian terhadap sesuatu. Epohe merupakan cara pandang lain yang baru dalam melihat sesuatu. Kita belajar menyaksikan apa yang tampak sebelum mata kita memandang, kita menyaksikan apa yang dapat kita bedakan dan deskripsikan.

Dalam epoche, menurut Moustakas (1994:33), pemahaman, penilaian, dan pengetahuan seharihari dikesampingkan dahulu, dan fenomena dimunculkan dan direvisi secara segar, apa adanya, dalam pengertian yang terbuka, dari tempat yang menguntungkan dari ego murni atau ego transendental.

\subsection{Reduksi}

Reduksi merupakan kelanjutan dari epoche. Bagi Husserl, manusia memiliki sikap alamiah yang mengandaikan bahwa dunia ini sungguh ada sebagaimana diamati dan dijumpai. Namun, untuk memulai upaya fenomenoloogis, kita harus menangguhkan kepercayaan ini. Inilah yang dimaksud dengan reduksi fenomenologis, atau disebut pula reduksi transendental, atau epoche itu sendiri. Melalui reduksi ini, kita melakukan semacam netralisasi, bahwa ada tidaknya dunia bukanlah hal yang relevan (Bertens, 1981:103).

Reduksi dilukiskan sebagai gerak kembali kepada suatu kesadaran transendental. Di depan kesadaran transendental itu, dunia terentang dengan kejernihan tanpa kegelapan apa pun (lihat Bertens, 1987:36). Dunia adalah dunia-sebagaimakna dan reduksi fenomenologis adalah idealistis dalam arti suatu idealisme transendental yang menganggap dunia sebagai suatu kesatuan-nilai tak terpisahkan yang dimiliki bersama oleh dua orang, di mana perspektif-perspektif mereka bercampur baur. Dengan demikian, mereka bisa saling berkomunikasi.

Reduksi fenomenologis. Kita harus memilah pengalaman-pengalaman kita untuk mendapatkan fenomena dalam wujud semurni-murninya. Segala sesuatu tampak pada kita .... Fenomena yang menyodorkan diri sebagai hal yang nyata ada itu tidak boleh kita terima begitu saja... Keputusan itu harus ditangguhkan. .. Setelah itu kita harus memandang atau menilik apa yang kita alami di dalam kesadaran kita. Apa yang kita tunda itu adalah berbagai pandangan kita yang sudah kita miliki sebelum kita menyelidiki apa yang tampak itu(Bagus, 2002:940-941).

Reduksi-fenomenologis-transendental. Dalam istilah ini, digunakan kata transendental karena hal itu berlangsung di luar keseharian menuju ego-murni di mana segala sesuatu dipahami secara segar, seolah-oleh untuk pertama kalinya. Reduksi ini juga disebut fenomenologis karena hal ini mentransformasikan dunia ke dalam suatu fenomena. Disebut reduksi, karena hal ini mengarahkan kita ke belakang pada sumber makna dan eksistensi dunia yang dialami (Schmitt, 1967, dalam Moustakas, 1994:34).

Dengan demikian, seorang fenomenolog hendaknya menanggalkan segenap teori, praanggapan, serta prasangka, agar dapat memahami fenomena sebagaimana adanya (Delfgaauw, 2001: 105).

\subsection{Intersubjektivitas}

Kita hidup bersama orang lain. Kita berada dalam orang lain, dan orang lain pun berada dalam kita. Dengan demikian, hal ini memungkinkan kita saling berkomunikasi untuk terus saling memahami. Pengalaman saya tentang orang lain muncul sejalan dengan pengalaman orang lain tentang 
saya. Dan segala sesuatu yang saya pahami tentang orang lain didasarkan pada pengetahuan dan pengalaman masa lalu saya.

\section{Fenomenologi sebagai Metode Penelitian}

Fenomenologi merupakan upaya pemberangkatan dari metode ilmiah yang berasumsi bahwa eksistensi suatu realitas tidak orang ketahui dalam pengalaman biasa. Fenomenologi membuat pengalaman yang dihayati secara aktual sebagai data dasar suatu realitas.

Kata What dan Berg (1995:417), Phenomenologist, . . ., are not at all in the bussiness of trying to to explain why pepople do what they do. Rather, they interested in explaining how people do what they do; according to costructs they manage to organize their daily lives, especially their communications between each other. Jadi, peneliti dalam studi fenomenologi tidak tertarik mengkaji aspek-aspek kausalitas dalam suatu peristiwa, tetapi berupaya menggeledah tentang bagaiamana orang melakukan sesuatu pengalaman beserta makna pengalaman itu bagi dirinya.

Fenomenologi juga mempelajari dan melukiskan ciri-ciri intrinsik dari gejala sebagaimana gejala itu menyingkapkan dirinya pada kesadaran (Bagus, 2002:236). Metode yang digunakan adalah deskriptif, dan bertujuan mengungkap intensionalitas, kesadaran, dan "dunia-kehidupan" (Kuper dan Kuper, ed., 1996:749). Sebagai metode, fenomenologi merupakan persiapan bagi setiap penyelidikan di bidang filsafat dan bidang ilmu pengetahuan positif. Satu-satunya alat untuk itu adalah bahasa.

Di lain pihak, menurut Brouwer (1984:3), fenomenologi itu merupakan suatu cara berpikir khas yang berbeda dengan seorang ahli suatu ilmu. Jika ilmuwan positivis meyakinkan orang dengan menunjukkan bukti, maka fenomenolog menunjukkan orang lain mengalami seperti fenomenolog mengalaminya. Atas dasar ini, maka fenomenologi dapat dikatakan sebagai lukisan gejala dengan menggunakan bahasa. Seorang positivis, terbiasakan hanya melihat objek-objek yang tampak, dapat dilihat, didengar, dibayangkan, atau dipikirkan. Tetapi, seorang fenomenolog harus belajar tidak lagi melihat benda-benda, melainkan fenomena.

Fenomenologi menjelaskan fenomena dan maknanya bagi individu dengan melakukan wawancara pada sejumlah individu. Temuan ini kemudian dihubungan dengan prinsip-prinsip filosofis fenomenologi. Studi ini diakhiri dengan esensi dari makna (Creswell, 1998:40). Fenomenologi menjelaskan struktur kesadaran dalam pengalaman manusia. Pendekatan fenomenologi berupaya membiarkan realitas mengungkapkan dirinya sendiri secara alami. Melalui “petanyaan pancingan", subjek penelitian dibiarkan menceritakan segala macam dimensi pengalamannya berkaitan dengan sebuah fenomena/peristiwa. Studi fenomenologi berasumsi bahwa setiap individu mengalami suatu fenomena dengan segenap kesadarannya. Dengan kata lain, studi fenomenologi bertujuan untuk menggali kesadaran terdalam para subjek mengenai pengalamannya dalam suatu peristiwa.

Dalam memahami fenomena, fenomenologi memiliki metode atau langkah. Pertama, melihat fenomena sebagai esensi, sebagai fenomena murni. Fenomenolog melakukan reduksi. Yakni semacam abstraksi, melihat sesuatu dan menutup mata untuk hal lain. Reduksi yang pertama adalah menghadap sesuatu fenomena sebagai hal yang menampakkan diri dan tidak melihat hal itu sebagai hal yang ada. Reduksi yang kedua adalah kita melihatnya sebagai sesuatu yang umum. Kita melihat esensi. Kita tidak melihat orang sedang mengajar di kelas, misalnya, tetapi memandangnya sebagai dunia pendidikan. Reduksi ketiga adalah kita menutup mata untuk hal yang berhubungan dengan kebudayaan. Reduksi terakhir, reduksi transendental, adalah bahwa fenomena dilihat dari segi supra individual sebagai objek untuk suatu subjek umum.

Persoalan Objektivitas. Suatu fakta yang diteliti dalam perspektif fenomenologi bersifat subjektif, yakni berdasarkan penuturan para subjek yang mengalami fakta atau fenomena yang bersangkutan. Bagaimana mengatasi subjektivitas si subjek yang diteliti atau peneliti itu sendiri? 
Objektivitas dalam fenomenologi berarti membiarkan fakta berbicara untuk dirinya sendiri. Hal ini bisa dilakukan melalui epoche dan eiditik. Epoce adalah proses di mana si peneliti menangguhkan atau menunda penilaian terhadap fakta/fenomena yang diamatinya walaupun ia telah memiliki prakonsepsi atau penilian tertentu sebelumnya terhadap fenomena itu. Biarkanlah fenomena itu berbicara apa adanya, tanpa intervensi penilaian baik-buruk, positif-negatif, bermoral-tidakbermoral, dsb. dari si peneliti. Eiditik adalah memahami fenomena melalui pemahaman atas ungkapan-ungkapan atau eksspresi-ekspresi yang digunakan subjek. Dalam hal ini, peneliti melakukan empati, mencoba memasuki wilayah pengalaman pemikiran subjek melalui proses imajinatif.

\subsection{Prosedur dan Fokus Penelitian}

Studi fenomenologi mencari jawaban tentang makna dari suatu fenomena (lih. Denzin dan Lincoln, 1988:64)

Pada dasarnya, ada dua hal utama yang menjadi fokus dalam penelitian fenomenologi, yakni:

- Textural description: apa yang dialami oleh subjek penelitian tentang sebuah fenomena. Apa yang dialami adalah aspek objektif, data yang bersifat faktual, hal yang terjadi secara empiris.

- Structural description: bagaimana subjek mengalami dan memaknai pengalamannya. Deskripsi ini berisi aspek subjektif. Aspek ini menyangkut pendapat, penilaian, perasaan, harapan, serta respons subjektif lainnya dari subjek penelitian berkaitan dengan pengalamannya itu.

Dengan demikian, pertanyaan penelitian dalam studi fenomenologi mencakup pertanyaanpertanyaan sebagai berikut:

- Apa pengalaman subjek tentang sutu fenomena/ peristiwa?

- Apa perasaannya tentang pengalaman tersebut?

- Apa makna yang diperoleh bagi subjek atas fenomena itu?

\subsection{Pengumpulan Data}

Teknik pengumpulan data utama dalam studi fenomenologi adalah wawancara mendalam dengan subjek penelitian. Untuk memperoleh hasil wawancara yang utuh, maka wawancara itu harus direkam. Kelengkapan data dapat diperdalam dengan menggunakan teknik lain, seperti observasi partisipan, penelusuran dokumen, dan lain-lain.

\subsection{Analisis Data}

Terdapat prosedur penting dalam melaksanakan studi fenomenologis — sebagai hasil adaptasi dari pemikiran Stevick, Colaizzi, dan Keen - (lihat Creswell, 1998:54-55, 147-150; Moustakas, 1994:235-237) sebagai berikut:

(1) Menetapkan lingkup fenomena yang akan diteliti: Peneliti berusaha memahami perspektif filosofis di balik pendekatan yang digunakan, terutama konsep mengenai kajian bagaimana orang mengalami sebuah fenomena. Peneliti menetapkan fenomena yang hendak dikaji melalui para informan.

(2) Menyusun daftar pertanyaan: Peneliti menuliskan pertanyaan penelitian yang mengungkap makna pengalaman bagi para individu, serta menanyakan kepada mereka untuk menguraikan pengalaman penting setiap harinya.

(3) Pengumpulan data: Peneliti mengumpulkan data dari individu yang mengalami fenomena yang diteliti. Data diperoleh melalui wawancara yang cukup lama dan mendalam dengan sekitar $5-25$ orang. Jumlah ini bukan ukuran baku. Bisa saja subjek penelitiannya hanya 1 orang. Teknik pengumpulan data lain yang dapat digunakan: observasi (langsung dan partisipan), penelusuran dokumen.

(4) Analisis data: Peneliti melakukan analisis data fenomenologis.

(a) Tahap awal: peneliti mendeskripsikan sepenuhnya fenomena yang dialami subjek penelitian. Seluruh rekaman hasil wawancara mendalam dengan subjek penelitian ditranskripsikan ke dalam bahasa tulisan. 
(b) Tahap Horizonalization: dari hasil transkripsi, peneliti menginventarisasi pernyataanpernyataan penting yang relevan dengan topik. Pada tahap ini, peneliti harus bersabar untuk menunda penilaian (bracketing/ epoche); artinya, unsur subjektivitasnya jangan mencampuri upaya merinci point-point penting, sebagai data penelitian, yang diperoleh dari hasil wawancara tadi.

(c) Tahap Cluster of Meaning: Selanjutnya peneliti mengklasifikasikan pernyataanpernyataan tadi ke dalam tema-tema atau unitunit makna, serta menyisihkan penyataan yang tumpang tindih atau berulang-ulang. Pada tahap ini, dilakukan: (a) Textural description (deskripsi tekstural): Peneliti menuliskan apa yang dialami, yakni deskripsi tentang apa yang dialami individu; (b) Structural description (deskripsi struktural): Penulis menuliskan bagaimana fenomena itu dialami oleh para individu. Peneliti juga mencari segala makna yang mungkin berdasarkan refleksi si peneliti sendiri, berupa opini, penilaian, perasaan, harapan subjek penelitian tentang fenomena yang dialaminya.

(5) Tahap deskripsi esensi: peneliti mengonstruksi (membangun) deskripsi menyeluruh mengenai makna dan esensi pengalaman para subjek.

(6) Peneliti melaporkan hasil penelitiannya. Laporan ini memberikan pemahman yang lebih baik kepada pembaca tentang bagaimana seseorang mengalami sesuatu fenomena. Laporan penelitian menunjukkan adanya kesatuan makna tunggal dari pengalaman, di mana seluruh pengalaman itu memiliki "struktur" yang penting.

\subsection{Contoh Penelitian}

Untuk memberikan gambaran yang lebih ril, saya akan mencoba menyajikan sebuah contoh penelitian berjudul "The Essential Structure of a Caring Interaction: Doing Phenomenology" yang dilakukan oleh Doris J. Riemen (dalam Creswell, 1998:271-295).
Penelitian ini mencoba memahami fenomena perawatan para pasien yang dilakukan para perawat di rumah sakit. Pada bagian pengantar, peneliti menjelaskan pengertian perawatan dan penjelasan mengenai masih sedikitnya penelitian tentang perawatan.

Dalam identifikasi masalah/pernyataan masalah, peneliti mengajukan pertanyaan utama dalam penelitiannya: Berdasarkan sudut pandang pasien, bagaimanakah struktur penting dari interaksi perawatan antara perawat-pasien? Secara deskriptif, ia pun memaparkan tujuan dari peneliti ini. Selain itu, peneliti juga memberikan justifikasi tentang pentingnya penelitian di bidang ini dengan ditunjang oleh beberapa testimoni.

Pada tinjauan teoretis, peneliti menujukkan beberapa prinsip fenomenologi yang relevan, yakni pandangan dari Martin Buber tentang konsep I-thou relationship dan I-it relationship; dan Gabriel Marcel tentang konsep intersubjectivity. Pada bagian ini, dipaparkan pula bagaimana fenomena yang akan diteliti dalam kacamata fenomenologi.

Pada bagian metodologi, peneliti menjelaskan konsep-konsep kunci dalam penelitiannya. Selanjutunya, ia mengemukakan reviu hasil-hasil penelitian terdahulu yang relevan. Pengumpulan data dilakukan dengan melakukan wawancara dengan para pasen yang direkam, dengan meminta izin terlebih dahulu kepada pasien yang bersangkutan. Pada saat ini, pasien diminta: (1) mendeskripsikan pengalaman interaksi dengan perawat tertentu yang dipandang sebagai "tindakan perawatan"; (2) menjelaskan bagaimana perasaan pasien dalam interaksi tersebut; (3) mendeskripsikan pengalaman interaksi dengan perawat tertentu yang dipandang sebagai "bukan tindakan perawatan"; (4) menjelaskan bagaimana perasaan pasien dalam interaksi tersebut; (5) menjelaskan selengkap mungkin apa yang sedang didiskusikan, tanpa berhenti. Pada bagian ini, dijelaskan pula tahap-tahap analisis data dengan menggunakan metodologi yang dikembangkan Colaizzi. 
Terakreditasi Dirjen Dikti SK No. 56/DIKTI/Kep/2005

\section{Tabel 1: Pernyataan Penting dari Pasien Wanita mengenai "T indakan Perawatan"}

1. Mendengarkan dengan baik - betul-betul mendengarkan.

2. Berempati.

3. Berskap memahami.

4. Mendukung masalah saya.

5. Berbicara.

6. Berbicara kepada saya tentang segala sesuatu selain masalah penyakit.

7. Memebuat saya merasa seperti orang sehat.

8. Menyukai saya sebagai manusia

9. Duduk-duduk di pinggir tempat tidur saya.

10. Memegang tangan saya.

11. Bertanya kepada saya tentang sesuatu.

12. Melihat muka saya secara langsung.

13. Beberapa ungkapan verbal mengenai rasa tidak amannya.

14. Mengizinkan saya untuk mengetahuinya apaapa yang seharusnya ditakuti.

15. Kembali beberapa menit kemudian menanyakan apakah saya merasa nyaman.

16. Merasa aman dengan adanya ia di sana

17. Merasa lebih rileks.

18. Merasa damai dalam pikiran.

19. Saya tidak merasa sebagai sesuatu dalam pajangan.
20. Saya merasa sebagai manusia.

21. Bertindak cukup - tenang - gentle

22. Betul-betul perhatian.

23. Menghibur

24. Ia mengetahui sesuatu yang mengganggu saya.

25. Perawat yang menjelaskan.

26. Saya merasa sangat lega.

27. Saya merasa dirawat dengan baik.

28. Keibuan.

29. Menyapa dan menghampiri bila saya memerluk an sesuatu.

30. Berbicara "manis".

31. Mencoba membangkitkan harapan saya.

32. Ia mengetahui apa yang sedang ia lakukan.

33. Perhatian pada keluarga juga.

34. Saya merasa sangat akrab kepadanya.

35. Saya ingin melakukan sesuatu un tuknya.

36. Saya merasa nyaman bersamanya.

37. Memahami pasien dan keluarga sebagai individu.

38. Perhatian pada saya.

39. Perhatian pada apa yang saya katakan.

Contoh: Pernyataan 9-13 berasal dari transkripsi berikut: "Situasi yang saya temukan adalah, perawat mendengarkan dan sangat menunjukkan minat. Ia menunjukkan perhatian pada penyakit saya, juga pada saya sebagai manusia dan individu. Ia duduk di pinggir tempat tidur saya, yang menurut saya baik. Saya senang kedekatan seperti itu. Ia mendenarkan saya, ia memegang tangan saya, dan ia menanyakan sejumlah pertanyaan kepada saya, yang benanr-benar membuat saya tahu bahwa ia sungguh-sungguh mendengarkan saya. Terdapat perpedaan antara mendenagar sesuatu dan mendengarkan, dan ketika berbincang dengannya, ia akan menatap langsung pada muka saya. Ia tampak sangat pengertian. Ia tidak bersimpati dengan saya, tetapi saya dapat merasakan empati di antara kami berdua, memegang tangan saya, dan duduk pada pinggir tempat tidur. Ia bahkan mengemukakan beberapa perasaan tidak amannya sendiri."

Frase-frase dari transkripsi berikut merupakan beberapa duplikasi dari pernyataan-pernyataan penting dari transkripsi sebelumnya dan oleh karena itu tidak diulang lagi dalam daftar penyataan penting yang final: listened duplkasi dari nomor 1 (mendengarkan dengan baik - betul-benar mendengarkan); menyukai saya sebagai manusia merupakan duplikasi dari nomor 8; empati di antara kami berdua merupakan duplikasi dari nomor 2 (berempati).

Sumber: Creswell (1998:282).

Keterangan: Item-item pernyataan yang dicetak miring merupakan contoh deskripsi struktural, sedangkan yang dicetak normal adalah contoh deskripsi tekstural. Pada tabel berikutnya, silakan cermati, mana pernyataan yang termasuk kategori deskripsi tekstural dan deskripsi struktural. 


\section{Tabel 2: Pernyataan Penting dari Pasien Pria mengenai "Tindakan Perawatan"}

1. Perawat ada di sana.

2. Memegang tangan saya dan menelusur kening saya.

3. Membuat saya merasa nyaman.

4. Mencoba membuat saya nyaman.

5. Perawat akan datang jika saya mengebelnya.

6. Datang dengan sukarela.

7. Duduk.

8. Berbicara kepada Anda.

9. Benar-benar mendengarkan.

10. Merasa seperti saudara perempuan saya merawat saya.

11. Pergi keluar dengan cara dia.

12. Secara rutin ia datang kembali bila ia dapat membantu.

13. Ia menjaga saya sepajang waktu.
14. Membuat saya merasa baik.

15. Menunjukkan minat pada saya sebagai manusia.

16. Memberikan pada saya apa yang saya butuhkan terlebih dahulu, kemudian melakukan tugas keperawatan.

17. Menjelaskan kepada saya.

18. Bertanya kalau-kalau ada hal yang saya butuhkan.

19. Menghabiskan waktu dengan Anda.

20. Menyenangkan

21. Baik.

22. Merasa nyaman dalam sentuhan tangannya

23. Bersikap lembut.

24. Mengibur.

25. Betul-betul memperhatikan Anda merasa senang.

Contoh: Pernyataan 6-10 berasal dari transkripsi berikut: "Ia akan datang secara sukarela, duduk, dan berbicara dan mendengarkan - benar-benar mendengarkan. Ia selalu merapikan tempat tidur saya dan meyakinkan saya merasa nyaman. Hal itu membuat saya merasa dirawat oleh saudara perempuan saya."

Karena frase meyakinkan saya merasa nyaman merupakan duplikasi dari nomor 3, maka frase itu tidak dituliskan kembali.

Sumber: Creswell (1998:283).

Pada bagian pembahasan hasil penelitian, peneliti menyajikan data penelitian dalam bentuk tabel. Pertama-tama, peneliti memisahkan data yang berasal dari pasien laki-laki dan perempuan. Selain itu, peneliti pun membedakan data "tindakan perawatan" dan "bukan tindakan perawatan".

- Hasil wawancara terekam, oleh peneliti, ditranskripsikan secara tertulis.

- Peneliti menyarikan pernyataan-pernyataan penting dari hasil wawancara tersebut sebagai unit-unit makna, dan menyisihkan pernyataan yang berulang. Hasilnya disajikan dalam Tabel 1 sampai dengan Tabel 4.
- Selanjutnya, dicari formulasi makna dari pernyataan-pernyataan penting dari Tabel 1Tabel 4. Hasilnya disajikan pada Tabel 5 dan Tabel 6. Agar hasilnya akurat, peneliti membaca ulang keseluruhan hasil wawancara secara cermat.

- Peneliti mengorganisasikan makna-makna sebagaimana tersaji pada Tabel 5 dan 6 ke dalam kelompok-kelompok tema umum. Hasilnya dipresentasikan pada Tabel 7.

- Setelah itu, peneliti melakukan deskripsi mendalam tentang fenomena yang diamati, dan menghasilkan uraian pada Tabel 8 dan Tabel 9 . 


\section{Tabel 3: Pernyataan Penting dari Pasien Perempuan mengenai "Tindakan yang Bukan Perawatan"}

1. Saya merasa seolah-olah tangan saya terbanting.

2. Peraturan lebih penting dibanding manusia.

3. Ada kesewenangan dan sikap berubah-ubah pada diri perawat.

4. Ia memperhatikan alat-alat alih-alih memperhatikan saya.

5. Selalu muncul dengan ketergesa-gesaan.

6. Tidak memiliki waktu untuk berbincang.

7. Tidak mau berbincang.

8. Ia tidak menunjukkan minat pada apa yang harus saya katakan.

9. Ia berada di sana mengerjakan tugas-tuasnya dan kemudian pulang.

10. Ia tak mau mendekat - berdiri menjaga jarak.

11. Merasa seolah-olah saya memiliki penyakit menular yang akan menggasaknya.

12. Tak mau melihat saya pada mata.

13. Ia begitu bergegas.

14. Defensif.

15. Tidak menunjukkan minat pada orang sebagai keseluruhan.

16. Saya tidak merasa dalam kemudahan.

17. Saya merasa tidak nyaman.

18. Saya menjadi tertekan.

19. Saya merasa saya harus menjaga agar tak bicara.

20. Bersikap efisien ag berlebihan.

21. Tamapaknya tak ada sesuatu yang mengganggunya.

22. Tampak ia sungguh kasar.

23. Ia membuat saya lebih tegang.

24. Ia menunjukkan ia frustrasi.

25. Membuat saya frustrasi dan takut.

26. Saya sedih.
27. Tak bisa mencontohkan apa yang berlangsung.

28. Ia tak peduli apa yang ia katakan.

29. Saya merasa sekadar sebuah "kasus"

30. Saya dalam keadaan gelisah.

31. Pergi begitu saja, dan ia tidak akan datang.

32. Ia mengatakan "ya-ya" dan tidak datang.

33. Ia tidak dapat menjelaskan - "sekedar tanda".

34. Menakutkan saya pada kematian.

35. Bertindak seperti ia punya pekerjaan yang harus dikerjaka.

36. Tak mau memberikan perhatian ketika saya bicara dengannya - karena saya lebih tua.

37. Membuat saya merasa marah

38. Merasa tidak percaya diri bersamanya.

39. Takut.

40. Berjingkrakan ketika dokter ada di sana.

41. Meninggalkan peralatan di kepala saya, dan pergi dari ruangan.

42. Menuruh saya angun dan menjaga diri sendiri.

43. Saya merasa takut dan lemah.

44. Ia tak mau datang dan membantu.

45. Saya merasa pusing

46. Saya menangis.

47. Saya tak mau ia menyentuh saya.

48. Ia terlalu sibuk berbincang dengan para perawat lain untuk berbincang dengan saya.

49. Ia tak tahu apa yang sedang dilakukannya.

50. Saya tidak diobati sebagai manusia.

51. Seakan-akan saya ini tidak ada.

52. Tidak mau kembali ke rumah sakit itu.

53. Bersikap tak memberi perawatan.

54. Bertindak seperti jam kerja.

Contoh: Pernyataan 35-38 berasal dari transkripsi berikut: "Perawat bertindak seperti ia mempunyai pekerjaan yang harus dikerjakan dan saya harus bangun sendiri dan menjaga diri sendiri. Ia tidak menaruh perhatian ketika saya berbicara kepadanya (tidak dikira untuk membangunkan) karena saya lebih tua. Baik, yah, hal itu membuat saya merasa sangat marah untuk satu hal, dan itu membuat saya memiliki rasa kurang percaya pada perawat."

Sumber: Creswell (1998:284) 


\section{Tabel 4: Pernyataan Penting dari Pasien Pria mengenai "Tindakan yang Bukan Perawatan"}

1. Tidak menaruh perhatian pada apa yang Anda perlukan.

2. Sekadar mengerjakan apa yang harus ia kerjakan.

3. Ia tak berprinsip "tidak mengasihi berarti tidak memiliki kehormatan".

4. Berbinang dengan Anda singkat sekali.

5. Ia benar-benar tidak lembut.

6. Tampak ia sekadar merawat apa adanya.

7. Memberi suatu jawaban cepat pada Anda dan pergi mengerjakan urusannya.

8. Tidak mau bercerita padamu apa yang sedang dikerjakannya.

9. Meberi Anda jawaban sederhana seolah-olah Anda tak mungkin dapat memahami.

10. Bertindak seperti hal itu sebagai kebiasaan sehari-hari.

11. Melakukan suatu pekerjaan - melihat Anda seperti sebuah objek.

12. Memandang Anda seperti Anda berusia 10 tahun.

13. Mengangkat dan mengguncangkan jarinya pada saya.
14. Merasa seperti anak kecil yang diomeli.

15. Tidak datang ke ruangan.

16. Kurang memberikan kontak.

17. Efisien - tetapi tanpa aspek kemaunisaan.

18. Bel berdering tapi tidak datang.

19. Tidak memberikan informasi apa pun.

20. Memandikan saya seolah-olah menangani seekor anjing.

21. Ini penghinaan.

22. Mengikat saya ke tempat tidur - tak pernah bicara pada saya dan keluar.

23. Bicara keras dan lambat seolah-olah saya akan kehilangan kelereng saya.

24. Dapat memberikan "perawatan-kecil" tentang apa yang seya derita.

25. Sangat kasar - seakan-akan mencoret saya.

26. Tanpa kesadaran personal mengenai kenyamanan saya.

27. Bunyi suaranya dingin - tanpa perhatian.

28. Merasa tidak dibantu.

29. Membasuh saya seolah-olah saya sebuah boneka.

30. Saya tak punya nilai bagi dia.

Contoh: Pernyataan 7-12 berasal dari transkripsi berikut: "Hal lain, ia akan membawa Anda ke dalam pengobatan atau sesuatu, Anda akan mengajukan sejumlah pertanyaan dan ia akan memberikan jawaban cepat dan pergi lagi untuk urusannya. Ia tidak akan menceritakan apa yang sedang ia kerjakan atau lainnya, ia akan memberimu jawaban sederhana seolah-olah Anda tidak mungkin mampu memahami. Ia akan akan bertindak seperti perawatan itu sebagai urusan tiap hari. Ketika ia melakukan sesuatu seperti menggunakan termometer pada mulut Anda, itu sekadar melakukan sebuah pekerjaan dan ia akan berdiri di sana dan menatap Anda seakan-akan Anda tak lebih sebuah objek."

Sumber: Creswell(1998:285). 


\section{Tabel 5: Makna yang Terbentuk dari Pernyataan-Pernyataan Penting mengenai "Tindakan Perawatan"}

\section{Wanita}

1. Perawat benar-benar mendengarkan terhadap apa yang dikatakan pasien, merespon pada keunikan individu.

2. Perawat perseptif dan suportif pada masalah-masalah pasien yang dinyatakan dan tidak dinyatakan.

3. Kehadiran perawat secara fisik ketika duduk, berbincang, kontak mata langsung, mengenggam tangan, mendekatkan dirinya, membuat pasien merasa bebas berbicara.

4. Ineteraksi dalam tindakan perawatan (mencakup perilaku dan sikap) membuat pasien merasa sebagai manusia yang berharga dan tidak seperti benda tak bernyawa atau objek dalam pajangan.

5. Sikap kesukarealaan perawat untuk kembali melihat pasien, tanpa harus diminta, mengindikasikan dengan jelas sebagai sikap tindakan perawatan.

6. Perhatian yang bersifat individual pada pasien membuat pasien merasa nyaman, aman, damai, dan rileks.

7. Suara yang lembut dan perilaku yang mempesona mengesankan pada pasien sebagai perawatan, bukan ancaman atau merendahkan.

8. Rasa aman dirasakan pasien ketika dalam perawatan itu merasa diperlakukan oleh anggota keluarga.

9. Pertemuan dalam perawatan menimbulkan perasaan hangat pada pasien dalam melakukan sesuatu secara timbal balik dengan perawat.

\section{Pria}

1. Kehadiran perawat secara fisik ketika duduk, berbicara, dan memegang tangan membuat pasien merasa perawat sunguh-sungguh memperhatikannya sebagai seorang individu yang berharga.

2. Sikap kesukarealaan perawat untuk kembali melihat pasien, tanpa harus diminta, mengindikasikan dengan jelas sebagai sikap tindakan perawatan.

3. Tindakan perawatan dari perawat membuat dia merasa nyaman, rileks, aman, seolah-olah ia sedang dirawat oleh seoarang anggota keluarga.

4. Perhatian oleh perawat terhadap kenyamanan dan kebutuhan pasien sebelum mengerjakan tugastugas keperawatan diinterpretasikan oleh pasien sebagai tindakan perawatan.

5. Suara dan sikapnya baik, lembut, menyenangkan, mengesankan pada pasien dalam memberikan tindakan perawatan dan tidak merendahkan.

Sumber: Creswell (1998:286). 


\section{Tabel 6: Makna yang Terbentuk dari Pernyataan-Pernyataan Penting mengenai "Tindakan yang Bukan Perawatan"}

\footnotetext{
Wanita

1. Tindakan perawat yang selalu dalam tergesa-gesa, tanpa menyediakan waktu untuk sungguh-sungguh berbicara atau mendengarkan, merupakan indikasi bagai pasien mengenai kurangnya perhatian perawat pada pasen sebagai seorang individu.

2. Sikap peraw at yang kurang menunjukkan minat terhadap pasien sebagai manusia diinterpretasikan pasien bahwa tugas keperawatan tak lebih "hanyalah sebagai pekerjaan".

3. Tindakan perawat secara fisik dan cara bicaranya yang yang meremehkan dan merendahkan dipandang pasien sebagai tindakan yang bukan perawatan.

4. Perilaku fisik yang ditunjukkan perawat yang dingin, kasar, efisien yang berlebihan, secara kaku mengikuti aturan, menghindari kontak mata, tidak menaewarkan penjelasan, dan melihat hanya sekilas pada pasien membuat pasien merasa frustrasi, takut, tertekan, marah, khawatir, dan sedih.

Pria

1. Perawat yang tidak menaruh perhatian pada kebutuhan pasien tetapi memandang tugas keperawatan sebagai sebuah pekerjaan dipandang pasien sebagain tidakan bukan perawatan.

2. Ketidakhadiran secara fisik atau hanya hadir sebentar, penampilan yang superfisial perawat diinterpretasikan pasien bahwa perawat tidak memandang pasien sebagai seorang manusia yang berharga.

3. Suara perawat yang dingin, tindakan yang kasar dimaknai pasien di mana dirinya dianggap sebagai subjek yang bukan manusiawi manusia atau objek yang tak bernyawa.

4. Komunikasi secara verbal dan fisik dari seorang perawat yang membuat pasen merasa seperti anak malang merupakan penghinaan dan merendahkan, dan membuat pasien merasa tidak dibantu dan frustrasi.
}

Tabel 7: Pengelompokan Tema-Tema Umum

\section{Tind akan Perawatan}

1. Kehadiran Perawat

a. Kehadiran perawat secara fisik dan mental memudahkan pasien bila satu saat butuh.

b. Bagi pasien, kehadiran perawat terasa bermakna bukan saja ketika memanggilnya, tapi juga ketika memerlukan kehadiran perawat tanpa diminta.

2. Keunikan Pasien

a. Perawat mengenali keunikan pasien dengan sungguh-sungguh mendengarkan dan merespon kepada pasien sebagai individu yang berharga.

b. Pasien memandang dirinya diperlakukan oleh perawat sebagai manusia yang berharga.

3. Konsekuensi

Perhatian perawat secara individual kepada pasien menimbukan perasaan nyaman, aman, damai, dan rileks.

Tind akan yang Bukan Perawatan

1. Kehadiran Perawat

a. Kehadiran perawat secara fisik sekadar untuk melaksanakan pekerjaan.

b. Untuk pasien, kehadiran perawat secara fisik bermanfaat sedikit atau tidak sama sekali, bahkan ketika diminta.

2. Keunikan Pasien

a. Perawat tidak mengenali keunikan pasien karena perawat tidak "sungguh-sungguh mendengarkan" atau "terlalu sibuk" untuk menaruh perhatian pada pasiesn secara individual.

b. Pasien tidak dihargai sebagai individu yang unik oleh tindakan-tindakan perawat yang menghinakan dan merendahkan.

3. Konsekuensi

Kurangnya perhatian perawat kepada pasien menimbukan perasaan frustrasi, takut, tertekan, marah, khawatir, dan sedih.

Sumber: Creswell (1998:288). 


\section{Tabel 8: Deskripsi Mendalam mengenai "Tindakan Perawatan"}

Dalam suatu interaksi perawatan, kehadiran perawat secara eksistensial dipersepsikan oleh pasien sebagai lebih dari sekadar kehadiran fisik. Terdapat aspek kerelaan dirinya untuk pasien. Kerelaan perawat tersebut mungkin timbul untuk merespons permintaan pasien, tetapi lebih sering merupakan usaha sukarela dan tanpa diminta pasien. Kehendak perawat untuk memberi pada umumnya dipandang pasien sebagai sikap dan perilaku ketika duduk dan sungguh-sungguh mendengarkan dan merespon akan keunikan individu sebagai manusia yang berharga. Ketenangan, kenyamanan, dan rasa aman yang dialami pasien secara fisik dan mental merupkan hasil yang timbul langsung dan segera dari kebutuhankebutuhan pasien yang dinyatakan ataupun tidak dinyatakan, yang didiengar dan direspon oleh perawat.

Sumber: Creswell (1998:289)

Tabel 9: Deskripsi Mendalam mengenai "Tindakan bukan Perawatan"

Kehadiran perawat dengan pasien dipersepsikan pasien sebagai sekadar sebuah kehadiran minimal perawat secara fisik bagi perawatnya sendiri. Perawat dipandang sebagai berada di sana karena hal itu sebagai pekerjaannya dan tidak untuk membantu pasien atau memenuhi kebutuhan-kekbutuhan pasien. Berbagai respons dari perawat dilakukan dengan pengeluaran energi yang menimal dan terikat oleh aturan-aturan. Pasien memandang perawat yang tidak merespon permintaan untuk membantu sebagai tindakan bukan perawatan. Oleh karena itu, suatu interaksi yang tak pernah terjadi diberi label sebagai interaksi tindakan bukan perawatan. Perawat terlalu sibuk dan tampak terburu-buru untuk menghabiskan waktu bersama pasien dan oleh karena itu tidak duduk dan mendengarkan sungguhsungguh pada masalah pasien secara individual. Pasien jauh lebih tidak dihargai sebagai manusia yang unik karena ia diomeli, diperlakukan seperti anak-anak, atau diperlakukan sebagai bukan manusia atau objek. Dikarenakan tak ada penghargaan dan kurangnya perhatian, kebutuhan-kebutuhan pasien tidak terpenuhi, dan pasien memiliki perasaan negatif, yakni frustrasi, takut, tertekan, marah, khawatir, dan sedih.

Sumber: Creswell (1998:289).

Data penelitian ini selanjutnya ditunjukkan kepada para pasien yang menjadi informan untuk diminta pendapatnya, apakah sesuai atau tidak dengan kenyataan yang mereka alami.

Pada bagian pembahasan (diskusi), peneliti melakukan refleksi dengan cara mengaitkan hasil temuan penelitian dengan prinsip-prinsip fenomenologi.

Pada bagian kesimpulan dan implikasi, peneliti mengajukan kesimpulan dan implikasi bagi pendidikan keperawatan, penelitian keperawatan, praktek keperawatan, dan teori keperawatan.

Laporan penelitian ini ditutup dengan Ringkasan.

\section{Penutup}

Praktik penelitian fenomenologi sebenarnya tidak serumit bayangan kebanyakan orang ketika memahami fenomenologi dalam kajian filsafat. Pada dasarnya, penelitian fenomenologi ingin menggali dua dimensi saja: apa yang dialami subjek (orang 
yang diteliti) dan bagaimana subjek tersebut memaknai pengalaman tersebut. Pengalaman subjek, dalam hal ini, merupakan fenomena yang menjadi subject matter yang diteliti. Dimensi pertama merupakan pengalaman faktual si subjek, bersifat objektif bahkan fisikal. Sedangkan dimensi kedua merupakan opini, penilaian, eveluasi, harapan, dan pemaknaan subjek terhadap fenomena yang dialaminya. Dimensi kedua bersifat subjektif.

Namun, seorang peneliti fenomenologi tetap perlu memahami terlebih dahulu prinsip-prinsip fenomenologi. Tanpa memahaminya, ia tidak akan mampu menganalisis data penelitian yang sudah ditranskripsikan ke dalam uraian atau tabel dalam konteks fenomenolgi.

Hal yang perlu ditekankan adalah bahwa tahapan-tahapan penelitian yang dikemukakan di atas bukanlah prosedur baku dalam penelitian fenomenologi. Apa yang telah diuraikan hanyalah salah satu variasi metodologi penelitian fenomenologi yang dapat dipakai. Di luar itu, masih ada sejumlah prosedur yang dapat digunakan.

\section{Daftar Pustaka}

Bertens, K. 1981. Filsafat Barat dalam Abad XX. Jakarta: Gramedia.

. 1987. Fenomenologi Eksistensial. Jakarta: Gramedia.

Bagus, Lorens. 2002. Kamus Filsafat. Jakarta: Gramedia Pustaka Utama.s

Brouwer, M.A.W. 1984. Psikologi Fenomenologis. Jakarta: Gramedia.

Creswell, 1998. Qualitative Inquiry: Choosing Among Five Tradtions. Sage Publications.
Delfgaauw, Bernard. 2001. Filsafat Abad 20. Terj. Soejono Soemargono. Yogyakarta: Tiara Wacana Yogya.

Denzin, Norman K. dan Yvonna S. Lincoln, 1988. Straegies of Qualitative Inquiry. Thousand Oaks: Sage Publications.

Edgar, Andrew dan Peter Sedgwick. 1999. Key Concept in Cultural Theory. London and New York: Routledge.

Hardiman, F. Budi. 1993. Menuju Masyarakat Komunikatif: Ilmu, Masyarakat, Politik \& Posmodernisme Menurut Jurgen Habermas. Yogyakarta: Kanisius.

Kuper, Adam dan Jessica Kuper, ed., 1996. Esiklopedi Ilmu-Ilmu Sosial. Terj. Haris Munandar, Aris Aanda, Meri J. Binsar, Yanto Mustof, dan Tri Wibowo Budi Santoso. Editor Zubaidi. Jakarta: PT RajaGrafindo Persada.

Littlejohn, Stephen W. 2002. Theories of Human Communication. 7th edition. Belmont, USA: Thomson Learning Academic Resource Center.

Littlejohn, S.W. and K.A. Foss. 2005. Theories of Human Communication. 8th edition. Belmont, USA: Thomson Learning Academic Resource Center.

Maliki, Zainuddin. 2003. Narasi Agung: Tiga Teori Sosial Hegemonik. Surabaya: PAM.

Moustakas, Clark. 1994. Phenomenological Research Methods. New Delhi: Sage Publications.

Suprayogo, Imam, dan Tobroni, 2003. Metodologi Penelitian Sosial-Agama. Cetakan ke-2. Bandung: Remaja Rosdakarya.

Watt, James H. dan Sjef A. Van den Berg, 1995. Research Methods for Communication Science. Boston: Allyn and Bacon. 